Rassegna- Pregledni rad-Review CDU-UDKCDU-UDK-UDC 27-36(460.11)"653"

$27-36(450) " 653 "$

27-57(460.11Santiago de Compostela)"653"

27-57(Monte Sant'Angelo)"653"

DOI: 10.32728/studpol/2019.08.01.05

\title{
THE COMPOSTELLAN DEVOTION AND THE MICHAELIC ONE ALONG THE SHEEP TRACKS: THE CASTEL DI SANGRO - LUCERA CASE IN SOUTHERN ITALY
}

\author{
Antonella Palumbo
}

\begin{abstract}
The following paper wants to explain in a generic way the importance of two sacred and charismatic medieval characters such as Saint James the Greater from Santiago de Compostela in Spain and Saint Michael Archangel from Monte Sant'Angelo in the South of Italy, through their main icons, the devotions, the anthropological approaches and the history of the pilgrimages that have called so many people in their own cities.

Santiago de Compostela and Monte Sant'Angelo were two of the most important places in the Middle Age. The representation of the saints and their actions, which are described in ancient literary texts, explains the origin of the cults and the following development of the pilgrimages both through the main routes and through the alternative routes known as "tratturi" or sheep tracks. Especially for the Castel di Sangro - Lucera sheep track there are traces referred to the saints not only in the villages touched by the grassy track, but also on the path itself.

There are aspects that are expressed better than others and they are essential for the important "Civilization of Pilgrimages" as the icons and the architectural structures: they can be defined as functional artistic ways
\end{abstract}


to communicate to all people not only in the past.

So, historical and artistic studies, but also anthropological and literature fields of study are the relevant methodological approach to better figure out the history of the compostellan and michaelic pilgrimages.

Keywords: Pilgrimage, routes, Saint James, Saint Michael, sheep tracks, worships 


\section{INTRODUCTION}

Santiago de Compostela and Monte Sant'Angelo have always been the most attractive places for the devotees. The Spanish town has Saint James the Greater as its patron and it preserves the saint's relics. Saint James had a strong charisma with people, since he was one of closest Apostle to Christ together with Saint Peter and Saint John. From the 9th century, with the discovery of Saint James's tomb, the first pilgrimages began initially around the place itself; then, they involved all the Iberian territory up to the final international expansion. The famous Camino Francés or Camino de Santiago was constituted after some centuries as a consequence of that expansion and it soon became an authentic "natural linkage" which, both symbolically and materially, connected the Northern Christian kingdoms and the southern countries occupied by Muslims. This was a decisive aspect that originated the pilgrimage to Santiago de Compostela and influenced most important artistic works concerning the saint and his worship.

In the 5th century there was the first apparition of the Archangel on the Monte Sant'Angelo, the first place in a Western country. The history about his worship is described in the important book contained in the Liber de apparitione sancti Michaelis in monte Gargano or better known as Apparitio. In this work three significant episodes concerning the michaelic devotion are explained, namely the episode of the bull and the arrow; the one of the battle between Lombards and Byzantines and the episode of consecration of the Basilica by the same Archangel. Furthermore, there are other two relevant michaelic sacred places in Europe: Mont SaintMichel au péril de la mer from Normandy in France and the Sacra di San Michele in Val di Susa from Piemonte in Italy. According to the famous passage of the Chronica the three michaelic shrines highlight a symbolic, historical and spiritual connection among the religious centres chosen by the Archangel himself. Moreover, the Sacra in Val di Susa is halfway between the other two ones, pointing out that the real intention was to create a close connection among the michaelic centres through a only path, known as the Via dell'Angelo. 


\section{THE CULTS OF SAINT JAMES THE GREATER AND SAINT MICHAEL THE ARCHANGEL: A CONFRONTATION}

The Galician saint was represented mainly in three ways: as an Apostle, as a pilgrim and as Miles Christi. The latter image, known as Santiago Matamoros, found its highest expression particularly in Spain, while the others were common in all countries. The image of Saint James as a pilgrim was surely among the most known and portrayed, since his attributes referring to the pilgrims and pilgrimages were iconic; on the other hand, the symbol that most strongly permeated the veneration of Saint James was the popular concha or shell, quintessential signum peregrinationis of the Camino de Santiago.

In addition to the pilgrimage to Santiago de Compostela, the other holy path that marked the history of itineraries was the one dedicated to the prince of heavenly armies, Saint Michael from Monte Gargano in Puglia. The cult of the Angel is deeply rooted in the Greek-Byzantine tradition and the first information relating to its appearance in the Western countries dates back to the 5th century. The Miles Dei was venerated especially for his thaumaturgical power but besides this medical function, he had other characteristics such as the role of psychagogue, psychopomp, weigher of souls, celebrant and God's warrior against the Devil. Due to the martial feature of the Archangel, the Lombard dynasty was among the main promoters of Saint Michael's worship in the Western world.

The itinerary leading to Saint Michael's cave named Via Michaelica or Via dell'Angelo coincided approximately with the Via Francigena, which was an authentic road artery developed thanks to both the ancient Roman road system and the various human groups that occupied the Italian peninsula during the centuries. This path was one of the most important communication roads that connected main shrines such as Rome and Monte Sant'Angelo and that reached the ports of Puglia, where many devoted wayfarers set sail for the Holy Land. The Camino Francés and the Via Francigena could be considered as an only route where a large number of devotees travelled to the sacred destinations, especially during the Middle Ages. 
The cults of Saint James and Saint Michael have some aspects in common, including the role of psychopomp and the task of weighing the souls, known as psychostasia; these characteristics were present in both the cults which show common traits despite the differences.

The IV miracle, known as "The miracle of solidarity between pilgrims" and which is contained in the II book of the Liber Sancti Jacobi, refers clearly to the Apostle's role of psychopomp.

The miracle tells the story of the journey of thirty knights going from Lorraine to the Galician tomb; during that journey, a knight became suddenly ill and only one companion gave him support. The ill knight got worse and then died; his friend remained alone and prayed to the saint who miraculously appeared to him as a knight. Saint James took both the alive knight and the deceased one with him and brought them near the town of Compostela. At the end of the story, the Apostle reveals himself and tells to the others knights, through the surviving companion, to return to their homes since they had not assisted their ill friend (Moralejo, Torres and Feo 1999, 344-346) .

Another reference can also be traced in the famous "Letter of Saint James" where the role of the Galician saint as conductor of souls is more detailed. In fact, the story is inspired by the episode of Charlemagne's death narrated in the Historia Turpini, the Book IV of Liber Sancti Jacobi, in which the Apostle leads the emperor's soul in the glory of Heaven (Moralejo, Torres and Feo 1999, 482). As a consequence, there is an image of the saint both as psychopomp and protector since he welcomes the souls at death's door and guides them along the Milky Way to the paradise. That is why many cemetery areas, funereal chapels or burials with the garments of the pilgrim are dedicated to the saint or refer to him: devotees used to recommend themselves to the saint for the afterlife.

There is an image of Saint Michael accompanying the souls in a passage of Luke the Evangelist $(16,22)$, where angels escorts dead Lazarus in the afterlife; furthermore, this particular role of the Archangel sent by God to pick up and lead devoted souls before the throne of Christ emerges in other apocryphal texts as well; an example is the History of Saint Joseph and Dormitio Virginis. As for the Miles Christi, the psychopomp role of the Archangel is relevant in the antique texts too: the dying prayed the 
Archangel to take the souls that were about to leave the Earth in his custody and to accompany them to the afterlife.

In addition to the task of leading souls to the afterlife, the Apostle and the Archangel have another important characteristic in common: the psychostasia. Both the saints can weigh the souls and judge them worthy of the Kingdom of Heaven and we could find the two saints depicted, but just one of them is in the act of weighing the souls, as in the painting called "The Last Judgment" fresco in Santa Maria of Loreto Aprutino. The art work is of particular importance because shows Saint Michael who fulfil his task, but there is also a bridge where the souls have to cross, known as Saint James' bridge. The name of the bridge is clearly linked to the Apostle and connects him with the ancient Bridge of Judgment: in fact, the souls should cross the bridge so that the righteous could reach the afterlife without any obstacle, while the ones which were found guilty of serious sins fell in the infernal river below.

Along with the bridge, in the fresco Saint Michael is depicted in the act of weighing the souls with the help of a scale given by the Almighty; this characteristic can be found in the origins of the cult itself that sees Saint Michael as the Angel of Judgment and executor of divine decisions. It should also be noted that the psychostasia is ascribable to the classic context where the Greek god Hermes carries out this task; the prince of the angels inherits this role due to the very origin of his cult in the Greek-Byzantine context. The weighing of souls is often associated with their journey to the afterlife; according to the liturgical prayers, the Archangel weighs the souls and can intercede on their behalf during the divine judgment, amending the sins of those who were devoted to him during their life.

The representation of the bridge as a passage for the afterlife can be found in many cultures so its presence in the Christian world is not surprising. In some Italian regional areas such as Abruzzo and Sicily, the bridge represents an atonement journey or even a place where the souls passed before arriving in the afterlife; in fact, still today it is believed that who has not made the journey to Galicia to homage to the saint in life would have done it in death.

The journey to the afterlife represented symbolically an atonement way for those who had not observed the Christians rules in life and 
therefore they were not worthy of entering the Kingdom of Heaven. The custom of going to Galicia is determined by the fact that the town of Compostela has always attracted many devotees. Saint James had an enormous charisma on the crowds of devotees and this aspect contributed to the spread of the cult and to the constitution of his sanctuary in the remote land of Galicia, which became one of the most important religious centres and one of the most difficult to reach at the same time.

The belief of the journey to the afterlife is attested in another ancient example provided by one of the most important and widespread text during the medieval era, the Visio Pauli. In the text, the image of the bridge appears again and it is highlighted the role of Saint Michael as the interpreter and conductor of Saint Paul during his short journey into the afterlife. The Miles Dei takes with him and protects Saint Paul alive; before arriving in Paradise, the angel accompanies Paul to visit Hell and its pains, including a "bridge thin as a hair" where the souls of the honest crossed it successfully, while the souls of sinners fell downwards, swallowed by a black river and devoured by an infernal beast (Villari, 1974, 80).

This traditional belief is a symbolic representation of the common pilgrimage, but as it has said previously, the pilgrimage has to be made by the men has not gone in life to the sacred places; in this case the souls have to go to the holy shrines as Jerusalem and Monte Sant'Angelo, too. This last one is more than a belief, because Saint Michael is the Angel of the Death and he is by definition a psychopomp. In fact, the pilgrims headed to the michaelic shrine in Puglia used to ask to the Archangel not only the benevolence or the remission from sins, but also his intercession and protection in the last moments of their lives.

The ancient cult of the souls derives from pre-Christian believes and his official admission in the Christian religion begin when it was founded the All souls' Day, the second day of November. Since the XVI century and after the Council of Trento, the cult of the souls of the Purgatory and the belief that the dead can be return to their home had become stronger and stronger.

So, the bridge as a step toward the afterlife and Saint Michael's psychostasia and the path of the souls were significant aspects of the two saints which could be traced both in the sacred liturgy and in popular idea 
in medieval times. Saint James accompanied and protected men during the pilgrimage of life as well as Saint Michael watched and guarded those who journeyed and both the saints had the task of guiding the souls toward the afterlife.

\section{THE PILGRIMAGE TO COMPOSTELA AND THE ONE TO SAN MICHELE: A COMPARISON}

The bond between the two cults is also highlighted by the respective pilgrimages to the many chapels, sacred buildings and places dedicated to the saints. Along the Camino de Santiago there were often churches or shelters for pilgrims dedicated to the Archangel, as well as many sacred buildings dedicated to the Apostle could be met along the Via Micaelica or Via dell'Angelo.

For example, along the itinerary of Saint James there was the well-known church of San Miguel de Escalada which dates back to the 8th century and whose remains have been recently restored. Another important building is one of the oldest buildings of the city, the church of San Miguel dos Agros in Santiago de Compostela, whose origins go back to the 10th century. The presence of the above-mentioned buildings witnessed the strong devotion to the Archangel which is also put into even sharper focus inside the cathedral of Compostela itself. The church of Santiago de Compostela is carefully described in the Guide of the pilgrim, 5th book of the Liber; considering the narration, the church had an altar dedicated to Saint Michael inside which was located high on the stands of the apse and faced the West, towards the Western gate. Currently it doesn't exist anymore, but in the interior of the Capilla del Salvador, there is a remarkable Retablo, an altar-piece goes back to the XV century, with a statue of the Miles Dei, as evidence of his anterior existence in the church. Always considering the Guide, there were also nine towers in the medieval era, one of which was dedicated to the Miles Dei. Researchers are still debating on the latter tower since its ancient location is still difficult to determine.

The custom of consecrating altars or towers to Saint Michael toward the West was not a coincidence, but dated back to an ancient 
Carolingian habit that stressed the role of the warrior saint against the Devil, emphasising the aspect of protector and guardian of humanity. We must not forget that the Archangel was the patron of several Germanic peoples, such as the Lombards, the Franks and the Normands.

If there are references to the cult of Saint Michael in the pilgrimage of Saint James and in the town of Compostela, there are also deep traces of the cult of the Apostle in the city of Gargano and in the relative paths. In addition the mountain town itself, many signs can be found in other places and locations interconnected with the roads that lead to the shrine, such as the port cities of Puglia, the villages along the via Francigena and other inner places close to the central-southern Apennines. The main paths that led to Saint Michael's sanctuary were the Via Micaelica with the Via Sacra Langobardorum and the Strata Peregrinorum.

The Via Sacra Langobardorum is a route approximately coincided with the path of Valle di Stignano which included the villages of Santa Maria di Stignano, San Marco in Lamis, San Giovanni Rotondo, Casale di Sant'Egidio and San Nicola al Pantano. Pilgrims used to pass through these ancient religious centres because there were other sacred places as the monastery of San Matteo (which still has a very ancient library); there are some evidences which are related to the cult of Saint James.

The Strata Peregrinorum almost coincided with the ancient via Traiana and it touched important centres like Benevento and Troia; other villages were Sant'Eleuterio, Aequum Tuticum (near to Ariano Irpino), the ancient Aecae (Troia), Lucera, Arpi (near Foggia) and Siponto. The route continued toward Lucera, where there was a branch that led to the valley of Stignano and another one that went to Foggia. According to many scholars, the Strata Peregrinorum can be considered the main path confirmed by a document that says: "strata magnam que pergit ad Sanctum Michaelem" (Donofrio Del Vecchio, 2000, 27). 
Some traces of the cult of Saint James have been found in Benevento, in Lucera and in Troia. In Lucera still exists a church of Saint James with a small square in front of the church self.

However, these were not the only traces of Saint James on the roads taking to the sacred cave; in fact, in addition to the above mentioned routes, there were other roads that led to Saint Michael's shrine such as the famous tracks of grass or tratturi (sheep tracks).

\section{THE “TRATTURI” ROAD SYSTEM AND THE CASE OF CASTEL DI SANGRO - LUCERA}

One of the main characteristics of the pilgrimage of Saint Michael is the road network itself that highlighted and connected numerous places in the territory of the Apennines and that acted as a proper way of communication accessible to the pilgrims as well.

This "stack of roads" was at the origin of the thick road system that existed since old times in the territories from the Apennines to the Apulian Tavoliere. The long grassy paths were born due to the old phenomenon of transhumance: since many flocks and herds passed along these tracks, many refreshment points appeared, as well as shelters for the animals, taverns, churches and cavities. Moreover, since many tratturi and tratturelli (small sheep tracks) largely flew into today's Capitanata, many places or mountain caves were dedicated to Saint Michael. According to the anthropologist Maria Antonietta Gorga, devotional places dedicated to a pastoral divinity like these were normal since this kind of cult was very much felt by the transhumant. In fact, shepherds asked for divinity protection against dangers that they might encounter during the journey. As a consequence, there were many buildings such as churches and cavities along the sheep tracks where people could rest.

The tratturi were important ways of communication as well. Many pilgrims used the network of paths of grass to reach the sacred centres indeed, in particular to the Gargano in Puglia, in the South of Italy. Along the tracks early arose villages too; moreover, the number of existing buildings such as taverns, churches and post offices confirmed definitively both the socio-economic and the urban-religious development of inhabited 
centres spread along the tratturi.

The road system consisting in tratturi, tratturelli and mule tracks was very extensive and it roughly coincided with Abruzzo, Molise, Campania and Puglia territories. Even if there were several sheep tracks, it is possible to identify four ones for importance and length which went from Abruzzo to Puglia: l'Aquila - Foggia, Pescasseroli - Candela, Celano - Foggia and Castel di Sangro - Lucera. The latter was $127.4 \mathrm{~km}$ long and was functional to the tracks of Celano - Foggia and Pescasseroli - Candela because it allowed a deeper inroad into the inner territories of Molise to better exploit their pastures.

After a more detailed research on the mentioned tratturo Castel di Sangro - Lucera, it can be said that not only there were other devotions such as the cult of Saint Michael and the Virgin Mary, but there also were many signs of the presence of Saint James in the centres touched by the grassy track or those one connected with it or existing on the path itself, as the chapel of Saint James near Castropignano and the chapel of Saint Michael near Ripalimosani still existing (ASCB, Atlante n. 2, tavv. XXVIXXXI).

In particular, the signs of a deeply devotion to Saint James have been noticed in the final part of the path which corresponded to the ancient region of Capitanata; many centres show traces of the cult of Saint James in this territory and more specifically there are centres more related both saints and their tasks than others such as:

- In Rionero Sannitico still exists a Saint James' church;

- In Campobasso there were two ancient churches dedicated to Saint Michael, but currently not exist anymore;

- In Celenza Valfortore still exists a Saint Michael's church;

- In San Marco la Catola existed an ancient Saint James' church (ASFG, 1875-76, vol. 144, tav. 40).

The town of Pietracatella can be considered as a further practical example: in this place, not only there is a great devotion to Saint James, but he is one of the protectors both the living and the dead. In fact, his church is built on the top of a rocky hill whose interior is empty. It is interesting to highlight that people used to bury the bodies in the interior of the hill, 
below the church of Saint James, so they could recommend themselves to the saint to the afterlife (Di Vita, 2012, 7-15).

Actually, in the region of Capitanata there was one of the major joints roads that led both to Apulian ports and to the shrines of Saint Michael in Monte Sant'Angelo and Saint Nicholas in Bari. Moreover, according to the historian Cherubini, the spread of the cult of Saint James in villages and along the extensive European road network was so great despite the distance from the Galician sanctuary that each reference in toponymy or every sign of an old hospital entitled to the Apostle became more and more numerous. Indeed, this happened even for the tratturi and for the tratturo Castel di Sangro - Lucera; among the many villages along the track we can cite Alberona which not only celebrates the Galician saint, but it also has Saint James as a patron together with Saints John the Baptist and San Rocco; furthermore, in the cathedral there is a statue of the Archangel that confirms the local devotion to Saint Michael.

There are traces of the cult of the Apostle also in the town in Gargano, such as the small church dedicated to the crowned Virgin Mary located in Valle Portella: it shields a statue of the Apostle of recent manufacture and formerly it was entitled to the Galician saint.

Besides the already mentioned church, there is a tangible proof that confirms the cult of the Apostle in the city of the Archangel. In the Sacred Cave is kept a marble slab placed above the entrance of the wellknown Cava delle Pietre (Cave of the Stones) which shows at the centre the image of the Virgin on the throne crowned by the angels, while a side is represented an image of a pilgrim saint who has been identified as Saint James. Indeed, the icon has the typical attributes of pilgrimage such as the bordone (a pilgrim's walking stick) and the scarsella (a kind of purse), but the sign that identifies the image as an apostle is the presence of the book, symbol par excellence of the Apostles. 


\section{CONCLUSION}

The close bond that highlights as protagonists and links two of the emblematic figures of the world of pilgrimages, Saint James the Greater and Saint Michael the Archangel, is confirmed by the numerous traces marked by history and time. The respective paths and the countless pilgrims who have travelled thousands of kilometres to pay homage to the saints made possible and fortified this connection in time, leaving many fields still unexplored to investigate, such as the network of tratturi that still has much to reveal.

These sacred routes may have lost importance, but they are not definitely disappeared: that leads us to reconsider a period of great devoutness certainly, but also of commercial and economic recovery that has affected the whole Mediterranean area and a large part of peoples of different cultures and countries. The two religious centres surely remain famous places that continue to exercise and to preserve their mysticism and their immense charm beyond every temporal limit and historical condition. 


\section{REFERENCES}

ASCB (Archivio di Stato di Campobasso), Fondo Reintegra dei Tratturi, Atlante n. 2, «Nella provincia di Campobasso che attraversa i terreni di Pietracatella, Toro, Campodipietra, Campobasso, Ripalimosani, S. Stefano, Castropignano, Torella, Molise, Duronia, Civitanova, Chianci, Pescolanciano, Carovilli, Roccasicura, Forlì, Rionero verificato dal 16 Settembre 1881 al 16 Luglio 1883», Decreto Ministeriale del 17 Marzo 1875, tavv. XXVI-XXXI.

ASFG (Archivio di Stato Di Foggia), Fondo Dogana delle pecore, serie I, f. 18, voll. I-II, 1648-1652, Atlante di Capecelatro, p. 285.

ASFG (Archivio di Stato di Foggia), Fondo Reintegra dei Tratturi, «Copie eliografiche di piante tratturali», 1875-76, vol. 144, tav. 40.

Bango Torviso, I. 1993. El Camino de Santiago. 18-23, Madrid: Editorial Espasa-Calpe.

Bianco, R. 2014. 'San Giacomo di Compostella e la Puglia. Linee di una ricerca'. Compostella 35: 43-51.

Bronzini, G. B., 1980. 'Religione dei pellegrinaggi e religiosità garganica. Testimonianze letterarie e demologiche'. Lares XLVI, 1980: 167-184.

Castiñeiras González, M. A., 2000. 'La catedral románica: tipología aequitectónica y narración visual'. In Santiago, la catedral y la memoria del arte, ed. M. Núñez Rodríguez, 39-97. Santiago de Compostela: Consorcio de Santiago.

Caucci von Saucken, J., ed. 2003. El sermón Veneranda Dies del Liber Sancti Jacobi, 78-79, Santiago de Compostela: Xunta de Galicia.

Caucci von Saucken, P., ed. 1984. Il cammino italiano a Compostella: Il pellegrinaggio a Santiago di Compostella e l'Italia, Perugia: Università di Perugia.

Cavallini, A., ed. 2004. Per Omnia Saecula Saeculorum. Monte Procida (NA): Grafica Montese.

Cherubini, G., ed. 2000. Santiago di Compostella. Il pellegrinaggio 
medievale. Siena: Protagon Editori Toscani.

Corsi, P., ed. 1999. Pellegrinaggi, pellegrini e santuari sul Gargano, San Marco in Lamis: Quaderni del Sud.

Dalena, P., ed. 2003. Dagli itinera ai percorsi: viaggiare nel mezzogiorno medievale. Bari: M. Adda Editore.

De Gubernatis, A., ed. 1971. Storia comparata degli usi funebri in Italia e presso gli altri popoli Indoeruropei, Bologna: Forni Editore.

Di Nola, A. 1991. 'Il Passo di San Giacomo'. Italie et Mediterranée, 103: 217-272.

Di Nola, A. M. 1989. 'Il ritorno dei morti'. Rivista Abruzzese XLII: 278-79.

Di Vita, D., ed. 2012. Pietracatella. Campobasso: Palladino Editore.

Donofrio Del Vecchio, D. 2000. 'Itinerari e luoghi dell'antica viabilità in Puglia'. In Itinerari in Puglia tra arte e spiritualità, ed. M. Pasculli Ferrara, 26-28. Roma: Edizioni De Luca.

Eadem. 2005. 'Culto iacobeo in Puglia tra medioevo e età Moderna. La Madonna, l'intercessione, la morte'. In Santiago e l'Italia, ed P. Caucci von Saucken, 135-151. Perugia: Edizioni Compostellane.

Eadem. 2014. 'Il borgo di Alberona e la tradizione compostellana'. Santiago 24: $10-11$.

Eadem. 2017. La conchiglia e il bordone. I viaggi di San Giacomo nella Puglia medievale, Napoli: Edizioni Compostellane.

Eadem. 2017. "Peregrinatio ad limina Sancti Jacobi et Sancti Michaelis Archangeli: differenze e analogie nei culti di San Giacomo il Maggiore e San Michele Arcangelo". PhD thesis, University of Chieti Pescara.

Finamore, G., ed. 1981. Tradizioni popolari abruzzesi, Palermo: Edikronos. Gandolfi, A. 1999. 'I santuari, le feste e i pellegrinaggi nelle comunità pastorali centroappenniniche'. In La civiltà della transumanza, storia, cultura e valorizzazione dei tratturi e del mondo pastorale in Abruzzo, Molise, Puglia, Campania e Basilicata, ed. E. Petrocelli, 441-443. Isernia: Cosmo Iannone Editore. 
Gorga, M. A., 1991. 'Feste religiose e luoghi di culto sugli antichi sentieri della transumanza'. In La cultura della transumanza, ed. E. Narciso, 133137. Napoli: Guida Editori.

Idem, 2007. 'Le vie della transumanza'. In Cento itinerari più uno in Puglia, ed. G. Otranto, 62-70. Bari: Gelsorossso.

Idem, 2007. 'Note sulla tipologia degli insediamenti micaelici in Europa. In Culto e santuari di san Michele nell'Europa medievale, eds. P. Bouet, G. Otranto and A. Vauchez, 386-415. Bari: Edipuglia.

Idem. 1990. Il Molise: arte, cultura, paesaggi, Roma: Fratelli Palombi Editori.

Idem. 1991. 'Transumanza e religione popolare'. In La cultura della transumanza, ed. E. Narciso, 111-131. Napoli: Guida Editori.

Idem. 1997. 'Michele nella letteratura apocrifa del giudaismo del Secondo Tempio'. Vetera Christianorum 34: 219-229.

Idem. 1999. 'La Francigena e le vie romee'. In Il Mondo dei Pellegrinaggi. Roma, Santiago, Gerusalemme, ed. P. Caucci von Saucken, 137-186. Milano: Jaca Book.

Idem. 1999. 'La "Francigena”. Via dell'Angelo'. In Francigena, santi, cavalieri, pellegrini, ed. P. Caucci von Saucken, 238-260. Milano: Serra Club International.

Idem. 2010. Guida del pellegrino di Santiago, Milano: Jaca Book.

Infante, R., ed. 2009. I cammini dell'angelo nella Daunia tardoantica e medievale. Bari: Edipuglia.

Liebetanz, G., 1999. Camminandosi, Tratturo Tratturo. Campobasso: Iresmo.

Lofoco, L. 2010, 'Prime testimonianze del pellegrinaggio jacopeo in Abruzzo'. Compostella 31: 22-3.

Moraldi, L., ed. 2001. Apocrifi del Nuovo Testamento. Lettere, dormizione di Maria, Apocalissi, III. Casale Monferrato (AL): Edizioni Piemme.

Moralejo Losa, A., Torres Rodríguez, C. and Feo García, J., eds. 1999. 
Liber Sancti Jacobi, "Codex Calixtinus". Santiago de Compostela: Xunta de Galicia.

Otero Túñez, R. 2000-2002. 'El retablo del Salvador de la catedral de Santiago'. Abrente 32 - 34: 41-56.

Otranto, G., Carletti, C., eds. 1995. Il santuario di San Michele arcangelo sul Gargano dalle origini al X secolo, Bari: Edipuglia.

Otranto, G. 2003. 'Genesi, caratteri e diffusione del culto micaelico del Gargano'. In Culte et pèlerinages à Sant Michel en Occident. Les trois monts dédiés à l'archange, eds. P. Bouet, G. Otranto, A. Vauchez, 50-72, Roma: École Française de Rome.

Oursel, R., ed. 1980. Pellegrini del medioevo: Gli uomini, le strade, i santuari. Milano: Jaca Book.

Palumbo, A. 2013. 'I culti di Santiago e San Michele'. Santiago 23: 6-7.

Palumbo, A. 2014. 'Il borgo di Alberona e la tradizione compostellana'. Santiago 24: 10-11.

Palumbo, A. 2017. "Peregrinatio ad limina Sancti Jacobi et Sancti Michaelis Archangeli: differenze e analogie nei culti di San Giacomo il Maggiore e San Michele Arcangelo". PhD thesis, University of Chieti Pescara.

Paone, N. 1987. La transumanza. Immagini di una civiltà, Isernia: Cosmo Iannone Editore.

Puente, R., ed. 1997. La Iglesia mozárabe de San Miguel de Escalada, León: Editorial Albanega.

Péricard-Méa, D., ed. 2004. Compostela e il culto di san Giacomo nel Medioevo. Bologna: Il Mulino.

Ragonese, R., ed. 2011. Dallo spazio all'immagine. La semiotica, la geografia e l'arcangelo, Bologna: I libri di Emil.

Russi, V. 2007. 'Note di topografia storica sulla cosiddetta "Via Sacra Langobardorum'. In La via sacra Langobardorum, ed. P. Corsi, 123-150. Foggia: Edipuglia.

Schiraldi, G., ed. 2008. Storia di Alberona dalle origini al XIX secolo. 
Lucera: Catapano Grafiche.

Sensi, M. 2011. 'Monte Sant'Angelo al Gargano: il toro e la freccia avvelenata, la grotta e la stilla'. Compostella 33: 31-46.

Seppilli, A., ed. 1977. Sacralità dell'acqua e sacrilegio dei ponti. Palermo: Sellerio,

Sergi, G. 2009. 'Peregrinatio et stabilitas in due tradizioni cronachistiche valsusine'. In Pellegrinaggi e santuari di San Michele nell'Occidente medievale. Pèlerinages et sanctuaires de Saint-Michel dans l'Occident médieval, eds. G. Casiraghi, G. Sergi, 149-162, Bari: Edipuglia.

Singul, F. and Fernández Castiñeiras, E., eds. 2001. San Miguel dos Agros. Santiago de Compostela. Santiago de Compostela: Xunta de Galicia.

Villari, P., ed. 1974. Antiche Leggende e Tradizioni che illustrano la Divina Commedia. Bologna: Arnaldo Forni Editore.

Vázquez Castro, J. 2007. 'A falta de torres, buenos son campanarios. Las desaparecidas Torres del Ángel y del Gallo en la Catedral de Santiago de Compostela'. Quintana 6: 245-261. 